\title{
What makes a 'National' War Memorial? The Case of the Australian Ex-POWs Memorial
}

\author{
LACHLAN GRANT
}

Public History Review, vol 12, 2006, pp92-102

W ar memorials play an intricate role in forming Australian national identity. As public monuments in remembrance of a generation lost, their importance to the social fabric is the centrality they play to rituals and ceremonies that mark formal aspects of one of Australia's most important national days. ${ }^{1}$ War memorials represent the biggest communal arts project ever attempted. They seldom attract attention because they are so common amidst the urban landscape. ${ }^{2}$ War memorials within Australia represent both individual communities, within the towns and suburbs, and the nation, within the major monuments in the national and each state capitol. How, then, can a war memorial within a local community be considered a national memorial? Why does a war memorial need 'national' status and how is this legitimised? These issues confronted Ballarat's Australian Ex-POWs (POWs) Memorial and revealed how government bureaucracy and party politics can influence the future and potential public significance of a war memorial.

Initially, I thought that the issues confronting the Australian Ex-POWs Memorial were related to place of POWs within Australian national history and the difficulties of incorporating the POWs experience within the Anzac legend. ${ }^{3}$ Such difficulties had been inherent in the memorial's design which incorporated both modernist and traditional approaches to memorial architecture that highlight the tension between the ex-prisoners' stories and their place in the Anzac tradition. On one hand the modernist element in the design highlighted their differences. This comprised of a memorial wall listing the names of all Australian POWs from all conflicts. Traditional memorial forms - obelisks - confirmed the place of POWs in Anzac and in the Australian landscape commemorating Anzac. ${ }^{4}$ In recent years, however, it has becoming increasingly clear that POWs have in fact become the preeminent group of veterans following the original Anzacs. ${ }^{5}$ It was, therefore, not an issue of the memorial commemorating and remembering captivity. Other factors were at the heart of the matter.

The memorialisation and commemoration of POWs has chartered a distinctive course compared to other groups of veterans in Australia. Memorials to POWs have only began to be established in the past twenty years. Despite the popularity of POWs literature the act of public commemoration and remembrance for POWs in the form of physical memorials has been, until recently, largely 
neglected. ${ }^{6}$ 'In the sites of their captivity as at home,' wrote Ken Inglis in Sacred Places: War Memorials in the Australian Landscape, POWs have become 'subjects of delayed commemoration. ${ }^{, 7}$ While the POWs story has been kept alive in popular memory through literary means, the war memorial, 'as a social and physical arrangement of space and artifacts that keep alive the memories of those who were involved in war', has only in the last twenty years begun to publicly commemorate Australian POWs. ${ }^{8}$ Before Canberra's Duntroon Military College opened the National POWs Memorial in 1988 - the Changi Chapel, a reerected chapel built from scrap wood and metal by Australians interned in Changi - very few memorials to POWs existed in Australia. That the National POWs Memorial was located in the military college and not on Anzac Parade alongside other national monuments to servicemen and women is testament to the degree of ambivalence in which POWs were held at that time. ${ }^{9}$ Such a delay in commemoration for POWs may relate to Michael McKernan's finding that following the war, especially in regards to the issue of reparation payments by the Commonwealth Government, there was official concern that 'any special treatment given to former prisoners of war might weaken the resolve of future soldiers and encourage them to hand themselves over to the enemy, no matter how brutal the consequences might be. ${ }^{10}$

Even so, there are few memorials to POWs. They include obelisks raised in Lithgow, New South Wales, in 1959 and St George, Queensland, in 1965. A chapel was built with stone from Changi and railway sleepers from the ThaiBurma Railway at the school for military engineering at Casula, New South Wales, in 1966, and a wall with a memorial stone and seats was installed in King's Park, Perth. At Ulverstone in Tasmania a POWs Garden was created in 1970 while at Mornington in Victoria a POWs memorial wall and garden was unveiled in $1986 .{ }^{11}$ The Australian Services National Nurses Memorial in Anzac Parade, Canberra, was unveiled by Prime Minister Howard in 1999, highlighting the importance of internment in the popular memory of Australian nurses' wartime experiences. ${ }^{12}$ Most memorials relate to the Asia-Pacific theatre of the Second World War. During the 1990s a Sandakan Memorial Foundation, with the support of the Keating government, began creating a series of memorials to Australians who had died in Borneo on the infamous 'death marches' in 1945. Two individuals, Sir Edward 'Weary' Dunlop and Sir Albert Coates, both medical officers on the Thai-Burma Railway, have been honoured with statues, a rarity for individual soldiers in Australia. Dunlop's statues are located in Melbourne, his hometown of Benalla and at the Australian War Memorial in Canberra. Coates statue is in his hometown of Ballarat.

War memorials have also been raised in the places of the prisoner's suffering. Prime Minister Howard opened the Hellfire Pass Memorial in Thailand on Anzac Day 1998 though the significance of this memorial is the landscape itself - Hellfire Pass - a notorious 600 metre long cutting on the Thai-Burma Railway). Others were constructed at Changi, on Ambon (1967), at Sandakan (1986), Ranau in Borneo (1985) and at Bangka Island (1993) where Sister Vivian 
Bullwinkel, the lone survivor of the Japanese massacre of Australian nurses, unveiled a stone tablet. ${ }^{13}$ Whereas these memorials are dedicated to specific groups, incidents or local servicemen, the Australian Ex-POWs Memorial in Ballarat, opened with great fanfare in February 2004, was the first memorial to POWs that specifically honoured all Australia's POWs both living and dead, from all conflicts by naming on a single memorial each of Australia's 37,000 POWs from all wars.

Shortly after the opening of the Australian POWs War Memorial at Ballarat in February 2004 a debate flared over the official status of the memorial. Was in fact a 'national' memorial? This was sparked by the Ballarat City Council's request for an extra $\$ 500,000$ - in addition to the $\$ 200,000$ already provided by the Department of Veterans' Affairs for the memorial's construction - from the Federal Government towards upkeep and maintenance. ${ }^{14}$ This, however, had been a contentious issue since the official launch of the project in 1999. Despite this, it seemed that organizers anticipated the issue over the official status of the memorial would dissipate after the memorial's dedication ceremony.

The first inclination that the there would be disagreement regarding the 'national' status of the Australian Ex-POWs Memorial came in September 1999 when the Member for Ballarat, Michael Ronaldson, announced the ambitious project to the Federal house of representatives. Ronaldson stated that the Australian Ex-POWs Memorial 'will have national status, though it is not to be called a national memorial.' Further confusion arose weeks later in another speech to parliament when Ronaldson referred to the project as a "national memorial. ${ }^{15}$ The Federal Government, however, did not want the term 'national' to be associated with it.

In January 2001 the Ballarat Courier revealed that funding for the memorial was twelve months behind schedule. But it noted that further Federal government funding would not be forthcoming since the Minister for Veterans' Affairs, Bruce Scott, did not regard the Australian Ex-POWs Memorial as a 'national' project. The Minister had been advised that this was also the view of the RSL. 'Were the Federal Government to provide significant funds for the construction of a local memorial,' the Veterans' Affairs spokesman continued, 'it would set a precedent, as funding of that magnitude by the Government has been restricted to national memorials on Anzac Parade and international memorials of important sites where Australians have fought, suffered and died. ${ }^{16}$ A spokesman for the Minister also told Melbourne's Herald-Sun that while it was 'a worthy project,' it was 'not a national project. ${ }^{, 17}$

The response from the Australian Ex-POWs Memorial Appeal Committee project coordinator Les Kennedy was one of surprise: 'We consider it a national memorial and the Minister himself mentioned it as a national memorial when he launched the appeal. It cannot be a local memorial when it carries the names of POWs from all over Australia. ${ }^{, 18}$ Kennedy noted too that the only memorial to POWs, the Changi Chapel, was not accessible to the general public and that it was a memorial solely to POWs interned by the Japanese. ${ }^{19}$ Arguments about 
accessibility, however, could be equally applied to the site of the Ballarat memorial. Kennedy also revealed to the Courier a letter from the Minister for Veterans' Affairs office to the chairman of the appeal committee that stated:

National Memorials are normally but not always located in the parliamentary triangle in Canberra, particularly Anzac Parade, or in the grounds of the Australian War Memorial. Regardless of the memorials intended location, any plan to create a national memorial to honour the Australian POWs would require full endorsement and support of the national executive of the ExPOW Association of Australia.

Kennedy believed such endorsement was gained at the Ex-POW Associations 1997 national conference ${ }^{20}$ To make matters more difficult for the appeal committee, the National President of the RSL, Major General Peter Phillips, weighed into the debate, stating that the proposed Ballarat memorial could not be called a national memorial because one already existed. The Changi Chapel had been declared the national memorial in the 1980s 'at the urging of the POW Association'. But he added 'that's not to say Australians shouldn't be chipping in to build this memorial in Ballarat. ${ }^{21}$ The Ballarat Courier staunchly supported the Australian Ex-POWs Memorial Appeal Committee. One editorial observed that: 'the comments would seem to fly in the face of those made by our own Federal Member, Michael Ronaldson, in June 1999, when he announced donations to the appeal would be tax deductible. "The tax deductibility status recognizes that this is a national project". ${ }^{22}$ Although a nationwide fundraiser does not equal a national memorial, the Courier's editor argued that 'the claim that the national memorial should be located in Anzac Parade in Canberra is a cop-out'. Why, he asked, 'haven't the Federal Government or the RSL moved to establish a proper memorial there to recognize Ex-POWs?' The appeal, he concluded, 'would be better served if Bruce Scott encouraged Australians to donate to the appeal rather than have his spokesmen label it as nothing more than a local memorial. ${ }^{, 23}$

Catherine King, Labor member for Ballarat and Federal Member following the 2001 Federal Election, claimed that 'it is nonsense to suggest that unless the memorial is constructed in Canberra it has no meaning for veterans in the wider community. ${ }^{24}$ Following the dedication ceremony in 2004, King observed that while 'the government has made it clear that it does not consider the Ex-POWs Memorial as a national memorial for POWs... in time our memorial will naturally progress to become a national memorial - a transition that will not seek to take away the significance of the Changi Chapel memorial in Canberra but in my view will naturally occur as people like my brother in law make the pilgrimage to the memorial here in Ballarat seeking names of people they have loved. ${ }^{25}$

Despite the Federal government's claim that national memorials can only be built in Canberra, each of the state war memorials built in the decades following the First World War are all officially entitled 'national' memorials. Although, 
according to Ken Inglis, the use of the term 'national' in this sense 'embodies a perception, vigorous of the nineteenth century and not yet extinguished by federation' that each state of Australia represented a nation of its own. ${ }^{26}$ Nonetheless, although a monument in remembrance of the participation of Victorians who served the nation during the Great War, is not Melbourne's Shrine of Remembrance a memorial of national significance - and therefore - a national monument? However, symbolism, representation and recognition were not the defining factors regarding the Australian Ex-POWs Memorial's official nonnational status.

The significance of Federal Government's stance on the memorial's official status was revealed a matter of weeks after the memorial's opening. A Courier editorial raised the issue of responsibility the City of Ballarat now had for the memorial:

As all the ceremony dies down, it has become even more evident just how substantial and important a role the memorial will play in Ballarat's identity in years to come. The memorial will not only be a major tourist attraction, it will also be something of a spiritual centre for the city - a site of grieving, courage, of reflection and pride in our ancestry. Now, as a city, we must plan to ensure this site remains in the optimum condition it so clearly deserves. Ongoing maintenance will be a financial burden in need of attention... The grand efforts and tireless work that secured the construction of the memorial, must now be used as an inspiration for the rest of us to work together to ensure this marvelous monument retains its lofty place in the national consciousness. It, and the names inscribed upon it, deserve nothing less. ${ }^{27}$

The Ballarat City Council estimated that the financial burden to be almost $\$ 1.5$ million for the following five years - a figure nearing the actual cost for the memorial's construction in the first place. One third of this was expected to be provided from Federal Government coffers. ${ }^{28}$ This sum was to cover maintenance, lighting, car parking, landscaping, security and marketing but not the bigger plan which included a restaurant at Lake Wendouree, opposite the site of the memorial, an interpretive centre to create an 'experience', toilets and a tourist information centre. The Courier made the contradictory point that if the memorial were in Canberra it would be fully funded by the Federal Government. The Ballarat Council pledged $\$ 50,000$ a year to the five-year project, while $\$ 100,000$ was requested from the Victorian State Government. In a submission to the Federal Government, the council estimated that 100,000 people would visit the memorial within twelve months and spend more than $\$ 13$ million a year while the economic injection into the city was estimated to create 163 full-time positions, along with adding almost $\$ 8$ million into the Victorian economy. ${ }^{29}$ 
The City Council sought $\$ 290,000$ in Federal Government funds. A city delegation led by Mayor David Vendy met Vale regarding the proposal in April $2004 .^{30}$ In an announcement that 'outraged the City of Ballarat and Ex-POW veterans,' the Courier reported that: 'the Federal Government will not spend another cent on the Australian Ex-POWs Memorial in Ballarat':

Veterans' Affairs Minister Danna Vale yesterday labeled the memorial as "regional", therefore ruling it ineligible for future funding. "How could the Federal Government say that this memorial is not of national significance?" Ex-POWs Memorial Appeal project manager Les Kennedy asked. "There are over 35,000 names here of POWs from all over Australia." City of Ballarat Mayor David Vendy received a letter from Ms Vale yesterday, which rejected a funding request of $\$ 290,000$ dollars to help complete stage one of the project. "To treat it as a minor memorial is just a disgrace," Cr Vendy said. "I would have thought in an election year this would have been looked upon fairly favorably by the Federal Government, but to dismiss this funding application is very ordinary."

Ex-POW Viv Robinson commented that if was 'lousy of the Federal Government when they support all these things overseas and yet they don't support something of significance here... This is a big national attraction. ${ }^{31}$ While the Ballarat council and Ex-POW committee may have been 'outraged' and 'disgraced' at the decision, it was hardly surprising.

In response, the Department for Veterans' Affairs issued a media release entitled 'Australian Government Committed to Australia's POWs' in which Vale defended the government's contribution and commitment to support the Ballarat Australian Ex-POWs Memorial, while also confirming that the National POWs Memorial at Duntroon was officially considered the 'national' POWs memorial. The minister took great care to mention the significant benefits provided to veterans that were perhaps more important than expenditure on public memory via an overtly expensive war memorial in regional Australia. But she did not mention that whereas in 2001 ex-prisoners of the Japanese were awarded $\$ 25,000$ in compensation, those who were prisoners of the Germans or Italians were not considered worthy of this payment.

On letter writer to the Courier, however, raised a simple and pertinent question:

Was the POW memorial built without knowing where the funds for capital, operating and maintenance were coming from? Surely no such project can be approved unless total costs and funding having been established. Are we missing some point here? If not, when do heads start rolling? ${ }^{32}$ 
This highlighted the Ballarat City Council's desperation for the memorial to receive official 'national' status. The council did not wish to pay for the expensive maintenance and development costs from its own pockets alone thus the debate over the 'national' status of the memorial emerged from the bid to acquire further funds from Canberra. ${ }^{33}$

The debate over the memorial's 'national' status become an election issue during 2004 in the marginally held seat of Ballarat. And locals tried to use this to woo the Prime Minister. Howard was the Australian Ex-POWs Memorial Appeal Committee's preferred choice to dedicate the memorial and the committee even considered a postponement of the ceremony to allow him to attend. But given the committee's estimates of approximately ten former POWs passing away each week, the organisers did not want another delay. Howard, too, was preoccupied with the launch of a campaign for the marginal Western Australian seat of Hasluck. ${ }^{34}$ His absence at the openng was a particular snub to locals. And it was very surprising for some given that the POWs story in popular memory speaks to core values seemingly held so dear by the Prime Minister, especially that of mateship. Howard's veneration of the mateship ethos was evident in a speech made at the opening of the Australian War Memorial in Hellfire Pass, Thailand, on Anzac Day 1998:

As an English officer stood in the driving rain and watched a group of Australians sing, as they trudged back exhausted from their work he asked, 'Just what is it that these Australians have?' The answer, plain now as then, was that they had each other They had their mates. Mateship, courage and compassion, these are enduring qualities - the qualities of our nation. They are the essence of a nation's past and a hope for its future. ${ }^{35}$

Despite the Prime Minister's alacrity at identifying himself with stories promoting nationalist rhetoric and notions of national cohesion political expediency took first place.

The debate divided clearly along political lines. This was partly fuelled by the Courier and its support for the sitting member in the long absence of a Prime Ministerial visit to the city. A visit by the federal leader of the opposition, Mark Latham, in the lead up to the 2004 election added fuel to the fire. Stating that Latham's presence was 'another coup' for the Labor party, the Courier editorial claimed that the 'issues associated with Ballarat's Australian Ex-POWs Memorial have all fallen Labor's way.' 'The Prime Minister', it observed, 'did not attend the opening of the memorial - a matter that has not gone unnoticed in Ballarat... Mr Latham will today be happy to help consolidate a strengthening position for Labor in a relatively marginal seat, knowing that such outcomes across the country are essential if he is to have any hope of winning government. ${ }^{36}$ 
Latham did not fail to deliver on the Courier's expectations. Visiting the memorial, he told veterans that the memorial's significance spread further than the region, declaring the memorial to be of 'national significance. ${ }^{37}$ Soon after, Labor promised a funding package of $\$ 150,000$. At the announcement the Member for Ballarat told the press that 'the Howard government's refusal to provide further assistance and its assertion that the Ballarat memorial cannot be "national" is a legalistic smokescreen for disinterest. ${ }^{38}$ Perhaps the government did not wish to spend money on a seat that it perceived it could not win, especially without support of the influential though usually conservative local paper. $^{39}$

On the very last day of campaigning for the 2004 Federal election, Treasurer Peter Costello came to the party. In what the Courier described as a whirlwind visit, Costello arrived in Ballarat by helicopter. Joining Australian Ex-POWs Memorial Committee members and Ballarat ex-POWs at the memorial, Costello doubled Labor's promise of $\$ 150,000$ : 'I got out the correspondence', he told those assembled, 'I took the opportunity to come and see it and I think it's the right thing to do... As treasurer, I am making this commitment... I hope it's a memorial that reminds future Australians of the great sacrifices that were made.' When asked whether the government would reconsider recognizing the memorial's status as 'national', the Treasurer replied: 'the government has just recognized it with a contribution of $\$ 300,000$. Let's not get hung up with syntax. ${ }^{40}$ Although far less than the $\$ 500,000$ requested, Project Coordinator Les Kennedy stated - following the election in which Labour held the seat of Ballarat but the Liberal Government was returned to power - that it was 'very exciting' that the Liberals had 'come to the party. They kept us dangling on the end of a string., 41 Costello's visit was also perhaps enigmatic of an important development in Australian politics during the dying days of the 2004 of the Federal election. Like Costello, Howard made a whirl-wind visit to Australian football's perennial and most iconic battlers, the Western Bulldogs in the working-class suburb of Footscray, promising $\$ 20$ million to improve amenities.

The circumstances that had arisen regarding the Australian Ex-POWs Memorial's 'national' status were telling of the relationship between public history and memory. There was no degree of compromise in regard to this issue. The Courier and Ballarat leaders painted the issue black and white, stating on numerous occasions that the government had failed to understand the national significance of the memorial in response to the government's disinclination to provide further funding (even though the government provided a significant contribution to the memorial's construction in the first place). In response the government did not wish to look as if it had misinterpreted the memorial's significance and were perhaps embarrassed by the fact that such a memorial did not exist in Canberra. The Department for Veterans' Affairs' dismissive attitude and the perceived snubbing of the monument and Ballarat by the Prime Minister - a picture painted largely by the Courier - was extraordinary. This was especially so given that within popular memory, the story of Australian prisoners 
are prime examples of the Anzac ethos and part of Prime Minister Howard's nostalgic and nationalist vision of Australian remembrance.

The debate over whether the Australian Ex-POWs Memorial was a 'national' memorial or not raises a number of issues regarding the construction and continuation of dedicating war memorials in the Twenty-first Century. Key issues are dominant historical paradigms and pork barreling. It seems the trend following the Second World War to build utilitarian memorials - such as parks, hospital wards, sports complexes or schools - is out of fashion. ${ }^{42}$ From this stems the issue of whether or not such money should actually be spent on veterans and the families rather than public monuments. Regarding POWs, it is an issue that is raised by Stephen Garton, who asks: 'Which is more important - individual welfare or cultural representation'? ${ }^{43}$

Another underlying issue regarding the memorial's 'national' status is its location in Ballarat. The questions of why Ballarat, or why not Canberra, or Melbourne or Sydney for that matter, is simple. It was the foresight of a small group of dedicated people in Ballarat who saw a niche for such a memorial. Committee Member Tom Roberts explained in an opinion article that appeared in the Courier that:

Should the Federal Government have wished to erect such a memorial, it has had 100 years to do so, and a site available since the establishment of Canberra. Ballarat acted because noone else has done so. This memorial, acknowledged unique in the world, complements the Avenue of Honour - the longest in the world - and the Arch of Victory. It was the foresight of those individuals who initiated the concept, the combined efforts of the sub-committee members, and the generosity of the Ballarat City Council, the general public and Tattersall's organisation which has enabled the project to be brought to fruition...Why shouldn't citizens of Australia and overseas travel to Ballarat rather than Canberra? Currently it is a national monument in all but name. ${ }^{44}$

Whether or not the Ballarat memorial should be recognized as more important 'national' memorial than the Changi Chapel in Canberra is irrelevant. Both memorials are important to the nation and its diverse group of veterans. In a sense, it was a shame that this debate raged only within the pages of the Ballarat Courier and was not raised in a wider public forum.

Why the debate? If as Robert's states, the memorial is national in all but name what is the significance of it being recognized as a national memorial? Was the issue of the memorial being either 'national' or 'regional' simply a case of the city of Ballarat asking too much from the government? It appears that having realized it had received a white elephant from the Ballarat RSL, the City Council felt that the Federal Government should contribute significantly to maintenance and running costs. Essentially this issue was about money not the amgiguity of 
POWs within national commemoration. Despite the best intentions of those involved in the memorial's construction, the issue over funding may affect the potential significance and functioning of this particular memorial and more broadly signify how the past, or in this case representations of the past, can become political tools.

\section{ENDNOTES}

\footnotetext{
${ }^{1}$ On Australian war memorials see Ken Inglis, Sacred Places: War Memorials in the Australian Landscape, Melbourne, Melbourne University Press, 2001.

${ }^{2}$ Alan Borg, War Memorials: From Antiquity to the Present, London, Leo Cooper, 1991, p. ix.

${ }^{3}$ On the difficulties POWs have had incorporating their narratives within Anzac see Joan Beaumont, Gull Force: Survival and Leadership in Captivity 1941-1945, Sydney, Allen \& Unwin, 1988; Joan Beaumont, 'POWs in Australian National Memory', in Bob Moore and Barbara Hatley-Broad (eds), POWs, Prisoners of Peace: Captivity, Homecoming and Memory in World War II, Oxford, Berg, 2005; Stephen Garton, The Cost of War: Australians Return, Melbourne, Oxford University Press, 1996; Robin Gerster, Big-Noting: The Heroic Theme in Australian War Writing, Melbourne, Melbourne University Press, 1987; Hank Nelson, POWs: Australians Under Nippon, Sydney, ABC Enterprises, 1985; and, Hank Nelson and Gavan McCormack (eds), The Burma-Thailand Railway: Memory and History, Sydney, Allen \& Unwin, 1993.

${ }^{4}$ On the design and symbolism of the war memorial, see Lachlan Grant, 'The Australian Ex-POWs Memorial and the Incorporation of POWs in Anzac', in Kevin Blackburn and Karl Hack (eds), Proceedings and Papers of the Japanese Occupation: Sixty Years After the End of the Asia Pacific War Conference, Singapore, Nanyang Technological University, 2005, pp147-158.

${ }^{5}$ Garton states that POWs have been broadly seen as inheritors of Anzac in The Cost of War, p227. Furthermore, Beaumont states that the POW story has become a celebration of national identity in 'POWs in Australian National Memory', p194.

${ }^{6}$ An example of the popularity of POW literature is the fact that both Rohan Rivett's Behind Bamboo and Russell Braddon's The Naked Island have sold over 1 million copies.

${ }^{7}$ Inglis, p. 374.

${ }^{8}$ James Mayo, War Memorials As Political Landscapes: The American Experience and Beyond, New York, Praeger, 1988, p1.

${ }^{9}$ Kevin Blackburn has noted that despite the large attendance at its opening, the Changi Chapel at Duntroon has not become the focal point for Australian POW commemorations. Kevin Blackburn, 'Changi: A Place of Personal Pilgrimages and Collective Histories', Australian Historical Studies, vol 30, no 112, April 1999, p163.

${ }^{10}$ Michael McKernan, This War Never Ends: The Pain of Seperation and Return, St Lucia, University of Queensland Press, 2001, p166.

${ }^{11}$ Inglis, p368-70; News Bulletin: Official Organ of the Ex-POWs \& Relatives Association of Victoria, August 1997.

${ }^{12}$ Christina Twomey, 'Australian Nurse POWs: Gender, War and Captivity', Australian Historical Studies, vol 36, no 124, October 2004, p273.

${ }^{13}$ Inglis, pp370-4.

${ }^{14}$ The initial grant of $\$ 50,000$ had come from the Department for Veterans' Affairs regional war memorials project, entitled 'Their Service - Our Heritage', which had been set up to aid as many regional communities as possible. The $\$ 50,000$ was more than twelve times greater than the usual $\$ 4000$ funding limit under the regional memorials project. Additionally, the second injection of $\$ 150,000$ also came from a similar commemorative program, 'Saluting their Service.'

${ }^{15}$ Michael Ronaldson, 'Statements by Members: Taiwan and East Timor, Australian Ex-POWs Memorial', Hansard, 29 September 1999, p10980, at http://parlinfoweb.aph.gov.au/piweb/view document.aspx?id=180669\&table=HANSARDR, and Michael Ronaldson, 'Grievance Debate: East Timor, Australian Ex-POWs Memorial Appeal, Ballarat Electorate: Online Australia Field Day', House Hansard, 18 October 1999, p. 11775 at http://parlinfoweb.aph.gov.au/piweb/view document.aspx?id=183749\&table=HANSARDR, both accessed 26 July 2004.

${ }^{16}$ The Ballarat Courier, 19 January 2001.
} 


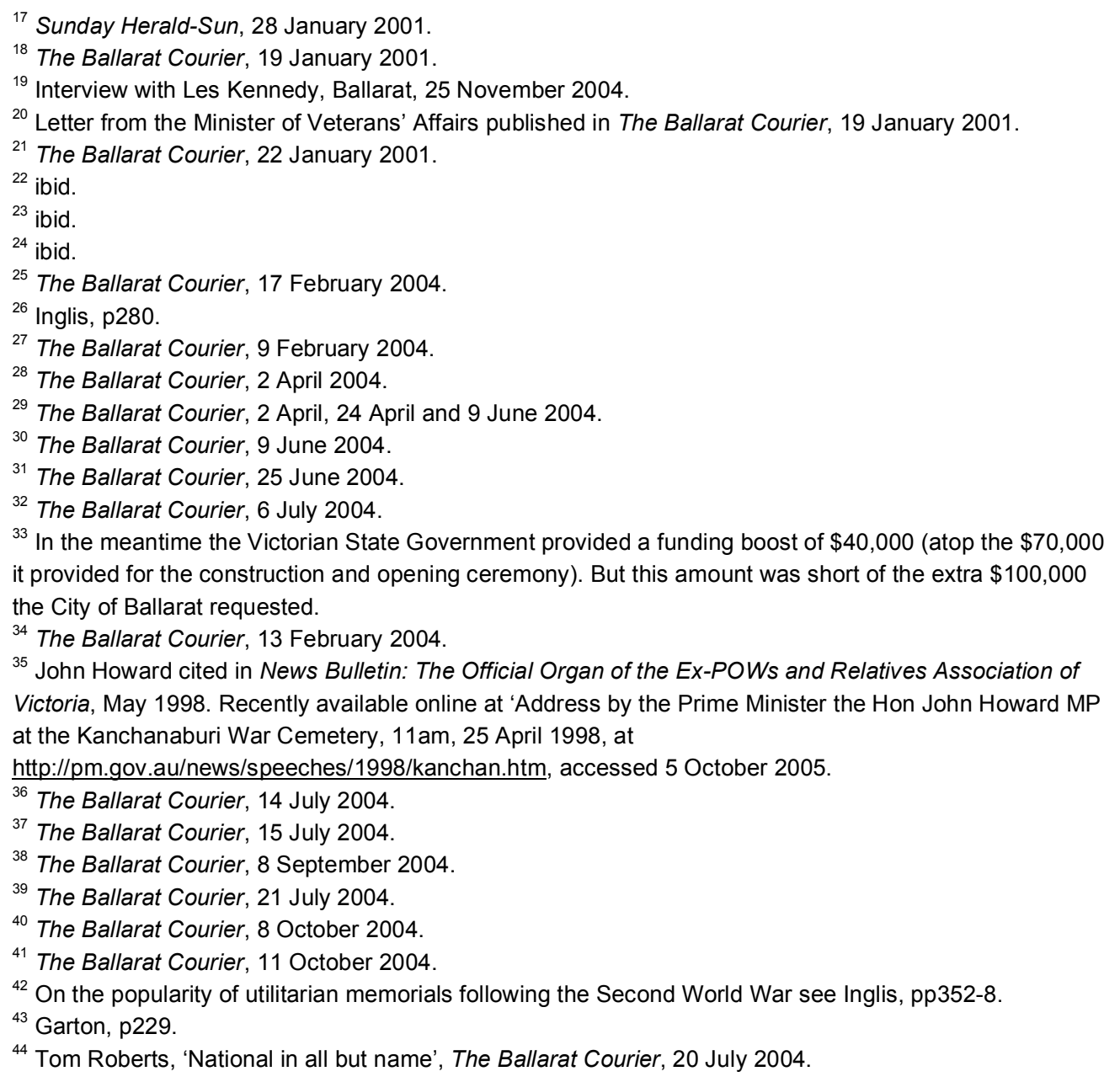

